\title{
K-12 Project Management Education: NASA Hunch Projects
}

Joe Morgan, Texas A\&M University, USA

Wei Zhan, Texas A\&M University, USA

Matt Leonard, Texas A\&M University, USA

\begin{abstract}
To increase the interest in science, technology, engineering, and math (STEM) among high school students, the National Aeronautics and Space Administration (NASA) created the "High Schools United with NASA to Create Hardware" (HUNCH) program. To enhance the experience of the students, NASA sponsored two additional projects that require universities to design and implement educational modules to be delivered over two (fall and spring) semesters to the six high schools in the area of project management. These modules exposed the students to project management concepts and tools that can be applied in their HUNCH projects. The benefits of the project management modules are: 1) acquiring knowledge in project management, 2) timely, costeffective execution of the HUNCH projects, and most important, 3) increased student interest in STEM. This article discusses the details of Texas A\&M University's design and implementation of the project management modules. The faculty members involved in the sponsored research projects designed and taught the educational modules. The educational modules were reviewed by the Project Management Institute-Clear Lake (PMI-CL) to ensure consistency with PMI's project management standards. Texas A\&M University partnered with three high schools during this project. Undergraduate students at Texas A\&M University who were enrolled in a project management course using project management techniques to complete their capstone design projects mentored the high school students. The interactions between the undergraduate and high school students proved beneficial to both parties. Pre- and post- tests in project management were designed and conducted in each high school. The data are used to analyze the effectiveness of student learning.
\end{abstract}

Keywords: K-12 Education; Project Management; Engineering Education; STEM

\section{INTRODUCTION}

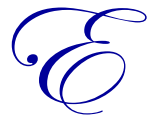

ducation in science, technology, engineering, and mathematics (STEM) has become a major concern in the United States in recent years (Knezek et al., 2005; Kimmel et al., 2006). It is widely accepted that the United States' leadership position in the world relies largely on its scientific and technical expertise (Hummel et al. 2012). In this technological era, as the demand for the workforce in the STEM fields continues to grow, more investments must be made in STEM education to prepare enough scientists and engineers who will create the innovations vital for the success of the U.S. economy. However, the current output from the U.S. educational system is struggling to meet this exponentially increasing demand for scientists and engineers (Lacey \& Wright, 2009). The impending wave of retiring baby boomer STEM professionals will worsen the situation in the next few years (Zhan et al. 2008). The shortage in workforce in STEM related fields has a negative impact on the economy through symptoms such as decreased competitiveness and less innovation.

Many countries in Asia and Europe surpass the United States in STEM education in both numbers and quality. Numerous assessments of high school and college student performance ranked the U.S. below $20^{\text {th }}$ place in the world (Alliance for Excellent Education, 2008). Both China and India have more engineering students than the U.S. Even South Korea, a country with only a sixth of the U.S. population, generates as many engineering students as the United States (National Science Board, 2004). The U.S. is gradually losing its competitive edge in the global economy to these countries that are able to produce more STEM talent. 
Despite the national unemployment rate remaining above $8 \%$, many companies cannot find enough qualified candidates for STEM jobs and must either rely on foreign workers or simply outsource the work to other countries, such as India and China, where labor costs are lower. Hiring employees with STEM skills from other countries can only help so much mainly because of limitations from immigration laws. In addition, many other countries are also increasing their efforts to attract talent in STEM from all over the world.

The consensus of industry, universities, and government is that the STEM workforce crisis is due to a shortage of domestic talent. The source of the shortage can be traced to the low retention rate of STEM students and lack of interest in STEM among K-12 students. There is a growing effort to enhance STEM education (National Science Foundation, 1996; Raymond, 2007; Sundaram \& Zheng, 2010). Federal and state governments are increasing funding in STEM education. There are more than 200 federal education programs designed to increase the number of students studying in STEM fields and/or improve the quality of STEM education (Library of Congress, 2008; Scott, 2012). For example, National Science Foundation (NSF) has a specific program called Science, Technology, Engineering, and Mathematics Talent Expansion Program (STEP) (National Science Foundation, 2012) that seeks to increase the number of students (U.S. citizens or permanent residents) receiving associate or baccalaureate degrees in established or emerging fields within STEM.

Many different approaches are being used to promote STEM education. An extensive status report on STEM education for undergraduate students was written by Fairweather (2010). Higher educational institutes are attempting to enhance curricula to increase the retention rate, among many other efforts (Center for Science, Mathematics, and Engineering Education, Committee on Undergraduate Science Education, 1999; DeHaan \& Schuck, 2003; Moore et al., 2000). Many universities have also participated in STEM outreach to K-12 students (Gelano et al., 2000; Hunter, 2006; Jeffers et al., 2004). STEM has been promoted in K-12 to increase students' interests at earlier ages (Douglas et al., 2004; Katehi et al., 2009; Kimmel et al., 2006; National Science Board, 2007). Some target elementary schools (Cunningham \& Hester, 2007; Cunningham et al., 2005; Lachapelle \& Cunningham, 2007), while a few even start as early as kindergarten (Cejka et al., Erwin \& Rogers, 2000). A majority of the work has been focused on high school engineering curricula (Douglas, 2006; Hirsch et al., 2003; Hirsch $e t a l$., 2005). In addition to the efforts made by higher educational institutes, there are organizations that are aggressively promoting STEM education. Project Lead The Way (PLTW) is one such organization. PLTW provides STEM curricular programs for middle and high schools across the U.S. (Ncube, 2006). There are several specialized public high schools that focus on STEM (Subotnik et al., 2010). Typically, the K-12 STEM education focuses on experiential learning and problem solving (Carlson \& Sullivan, 1999). Corporate sponsors are also increasing their support for STEM education at all levels. The goal of all these efforts is the same: to increase students' interest in STEM early, build on existing knowledge, provide them with practical experiences, and to sustain interest in STEM.

\section{NASA HUNCH AND PROJECT MANAGEMENT}

NASA, as a federal government agency, is one of the strong proponents and customers of STEM education. To increase the interest in STEM among high school students, NASA created the "High Schools United with NASA to Create Hardware" (HUNCH) program. NASA has been running the HUNCH program for nine years. HUNCH is an instructional partnership between NASA and high schools (or middle schools). Each year, students from high schools selected to participate in the HUNCH program work on space-related projects proposed by NASA or created by themselves under the guidance of high school science and engineering teachers and NASA engineers. The HUNCH program has the following objectives:

- $\quad$ to provide challenging project opportunities for students to gain hands-on experience,

- $\quad$ to expose students to professionals working in STEM careers,

- $\quad$ to build students' self-confidence in STEM areas,

- $\quad$ to teach students to view mistakes as learning opportunities as opposed to failures to reduce fear of taking risks,

- $\quad$ to spark student creativity and a passion for learning in STEM areas,

- $\quad$ to build students' sense of pride and accomplishment,

- $\quad$ to provide opportunities for students to determine if they are interested in pursuing STEM careers, and

- to develop an understanding of authentic engineering research and design. 
In 2012, NASA Johnson Space Center selected a total of six high schools in the vicinity of Houston to develop components for use by NASA. The projects proposed by NASA for 2012 include: 1) Washing Machine; 2) Exercise Machine; 3) Mock up of the International Space Station (ISS) Destiny Laboratory module; 4) A tool that quickly and simply measures all types of Hex and Allen sizes, 5) General Luminaire Assembly.

To enhance the experience of the students, NASA sponsored two supplemental projects that required universities to design and implement educational modules in the areas of project management for the six high schools to be delivered over two (fall and spring) semesters. Texas A\&M University was one of the two universities selected for these tasks. These modules were designed to expose the students to project management concepts and tools that could be applied to their NASA HUNCH project. The benefits of the project management modules are: 1) acquiring knowledge in project management, 2) timely, cost-effective execution of the NASA HUNCH projects, and most important, 3) increased student interest in STEM.

Studies show that at the college level, students tend to focus their efforts on the technical aspects of the projects and overlook the importance of other areas such as project management (Zhan \& Morgan, 2011; Zhan et al., 2009). Without a rigorous process to conduct the project, students will most likely use the trial-and-error method to attack technical challenges. As a result, the projects can go over budget and fail to meet deadline. Future engineers must learn early on that a process for product/system development must be followed in order to deliver the project on time and on budget. Early exposure to the product development process for engineering students have proven beneficial (Olds et al., 1990; Zhan et al., 2009). Project management is a necessary requirement for the successful execution of a large scale project (Heerkens, 2001; Kerzner, 2005; Milosevic, 2003; Newell \& Grashina, 2003; PMI, 2009). This is particularly the case when inexperienced students are the main workforce of the project. A successful project will have demonstrated the students' technical development, but just as importantly, will have enlightened them to the importance of the project management tenets that will guide them.

Many educators have discussed the methods of teaching project management effectively at the college level (Fisher et al., 2005; Hriso \& Clark, 2007; Smit, 1998). Project management is a necessary skill for engineers working in industry in the $21^{\text {st }}$ Century (Trilling \& Fadel, 2009). Due to its importance in the real-world, many training programs target the workforce in the public and/or private sectors for improvement in their knowledge and application of project management (Kuprenas \& Nasr, 2006; Kuprenas et al., 1999). However, only a limited amount of literature can be found in teaching project management in high schools (Byrne et al., 2008). Byrne listed twenty-one unique issues related to teaching project management in high schools; these include finding qualified mentors, mentor training, background checks, and security (Byrne et al., 2008). The assessment of effectiveness of student learning in high school setting is also a topic worth discussing.

\section{A UNIQUE APPROACH FOR LEARNING PROJECT MANAGEMENT}

Based on the lessons learned by Byrne et al. (2008), the Texas A\&M University Electronic Engineering Technology (EET) Program and the Project Management Institute - Clear Lake/Galveston (PMI-CLG) Chapter developed an innovative approach to introduce project management concepts and tools to the students working on the NASA HUNCH projects.

The team proposed an approach that leverages its curriculum development capabilities, industry expertise, and the energy and passion of undergraduate students to engage high school students in project management at an early stage in their lives. The four-fold approach combines the attributes and synergistic values of in-person workshops, teleconferencing interactions, on-line wiki-based documents, and presentations and videos to employ experiential learning processes. These processes allow high school students to develop technical skills in an environment conducive to learning while providing understanding of the value of project management tools to their future careers.

The teaming of Texas A\&M University and PMI-CLG took advantage of each organization's interests, creative strengths, and experience/expertise in developing high-quality, experiential learning opportunities for high school STEM teachers and students in the concepts and toolsets used by professional project managers. Leveraging established relationships with a number of high schools and middle schools in the greater Houston area, both organizations quickly developed and delivered meaningful project management teaching materials geared towards 
projects being undertaken by secondary educational programs participating in HUNCH-sponsored projects. The three faculty members and two PMI-CLG personnel involved in the sponsored research projects designed and taught ten educational modules. The educational modules were reviewed by PMI-CLG to ensure consistency with PMI's project management standards.

Undergraduate students at Texas A\&M University enrolled in a project management course and using project management techniques to complete their capstone design projects mentored the high school students.

Over the past five years, the EET Program has fully developed its experiential learning Capstone Design curriculum, in which project management tools have been extensively and successfully used (Morgan et al., 2005; Porter et al., 2002). During the first semester, the teams use PMI-based project management tools to plan their project through scope definition, scheduling, and costing. The Capstone students participated in the development and testing of these materials and processes as a part of their own prototype design activities. These college students then became the primary mentors for the high school teams. EET faculty coordinated and oversaw these interactions, but having young men and women at the college level actively involved in the interaction with high school students generated much higher levels of interest and engagement while realizing enhanced educational opportunities for both parties. The technical skill sets of the Capstone students in completing hardware/software design/development, testing, and documentation made them instantly relatable and acceptable to the high school teams developing technical solutions for the NASA HUNCH problem statements. The undergraduates reinforced the value and importance of project management in overall project success through their own Capstone design experiences.

The delivery of the lectures included eight in-person classroom lectures, one WebEx meeting, and one videotaping. In using this approach, the Texas A\&M / PMI-CLG team was able to deliver a comprehensive project management "learning by doing" environment. The three EET faculty members and two PMI members conducted the formal portion of the workshop. Once the workshop lessons were delivered, the students participated in exercises/activities that focused on their projects.

In preparing the packages, EET faculty integrated its graphical toolset approach to project management which has been documented in a recent paper published by the Journal of Management and Engineering Integration (Douglas, 2006). These graphical tools are easy to understand and use. Some of these tools were developed by EET capstone teams (Douglas et al., 2004; Douglas, 2006). The lectures were delivered in the following order:

\section{Lesson 1: Course Overview and Project Charter}

This lesson included the objective of the partnership among NASA, Texas A\&M University, PMI-CLG, and the high schools, project management overview, establishment of project charter, identifying the stakeholders, defining the concept of operation, and development of functional requirement. The requirements of weekly assignments, submitting reports, and grading were discussed.

\section{Lesson 2: Project Management Triangle}

This lesson included the introduction of the project management triangle (Fig. 1) in the context of a general system design process. Some basic project management terminologies such as milestones, deliverables, cost, scope, duration, WBS, RAM, and NLD were discussed.

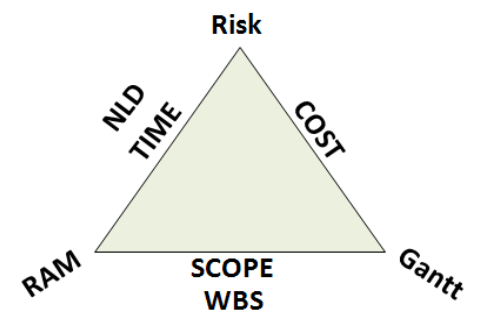

Figure 1: Project Triangle 


\section{Lesson 3: Quality Function Deployment}

This lesson was designed to help the students understand the process of establishing system design requirement based on the voice of customer. The importance of Voice of Customer and Mind of Customer was discussed. The Verbatim Analysis \& Sorting Table (VAST) technique was introduced to derive the customer root wants. The House of Quality (Fig. 2) was introduced to the students.

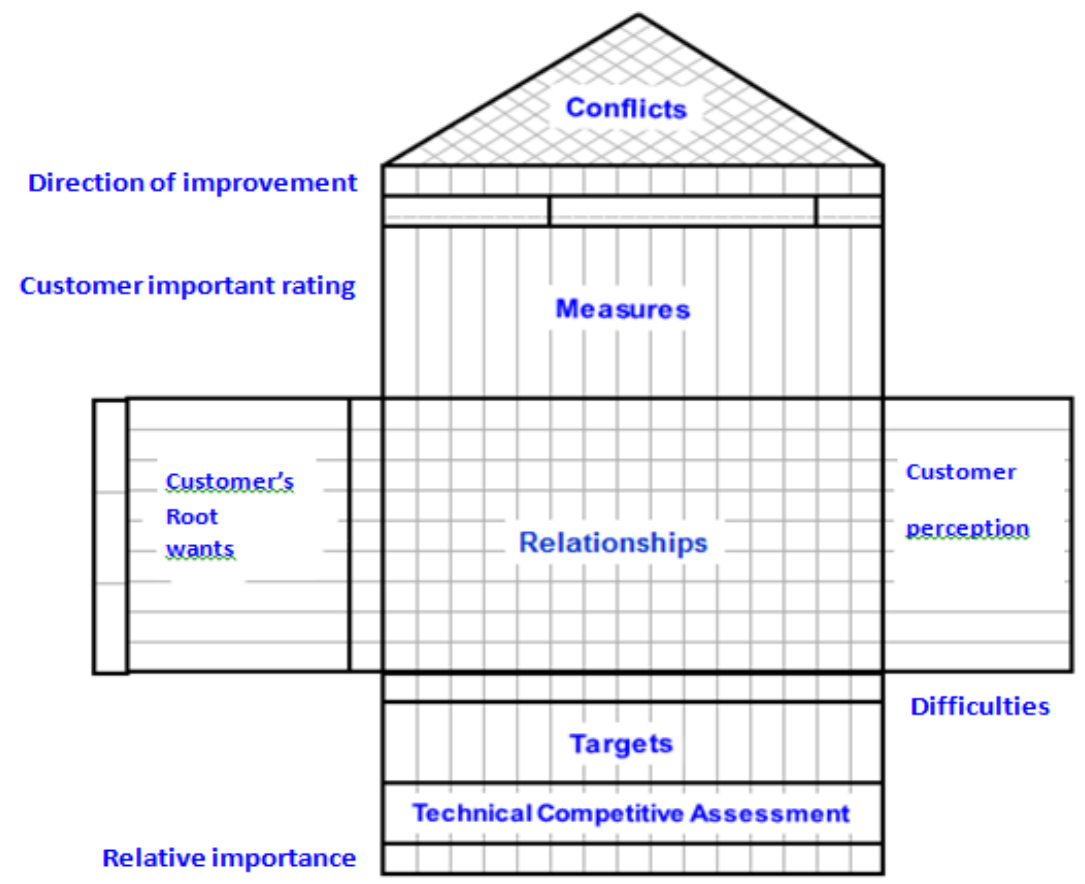

Figure 2: House of Quality

\section{Lesson 4: Work Breakdown Structure (WBS) and Responsibility Assignment Matrix (RAM)}

In this lesson, the concepts of WBS and RAM were introduced. Students used these tools to determine the resource requirements, tasks requirements, and the individual's responsibility for each task. This forced the teams to plan the overall projects in the early stage of the project which then allowed them to determine the project duration and critical path in the next lesson. These activities created buy-in by all team members while providing specific areas of responsibility for leadership for each team member.

\section{Lesson 5: Network Logic Diagram (NLD)}

Students learned how to define a task node by finding the early start, duration, early finish, late start, slack, and late finish (Fig. 3). Using the WBS developed in Lesson 4, students learned to build a NLD. They used the forward pass to find the project length and the reverse pass to find the critical path and the slack (or float) for each project work package.

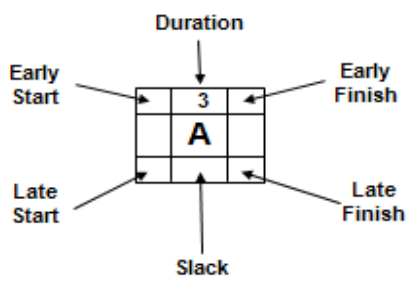

Figure 3: Task Node 


\section{Lesson 6: Risk Management}

The risk events, their probabilities and impacts were introduced in this lesson. The risk management process of "identify, evaluate, respond \& control" was taught. The USAA Risk Management Card (Fig. 4) was used to identify the risks. Risk responses of "eliminate, transfer, mitigate, and accept" were discussed.

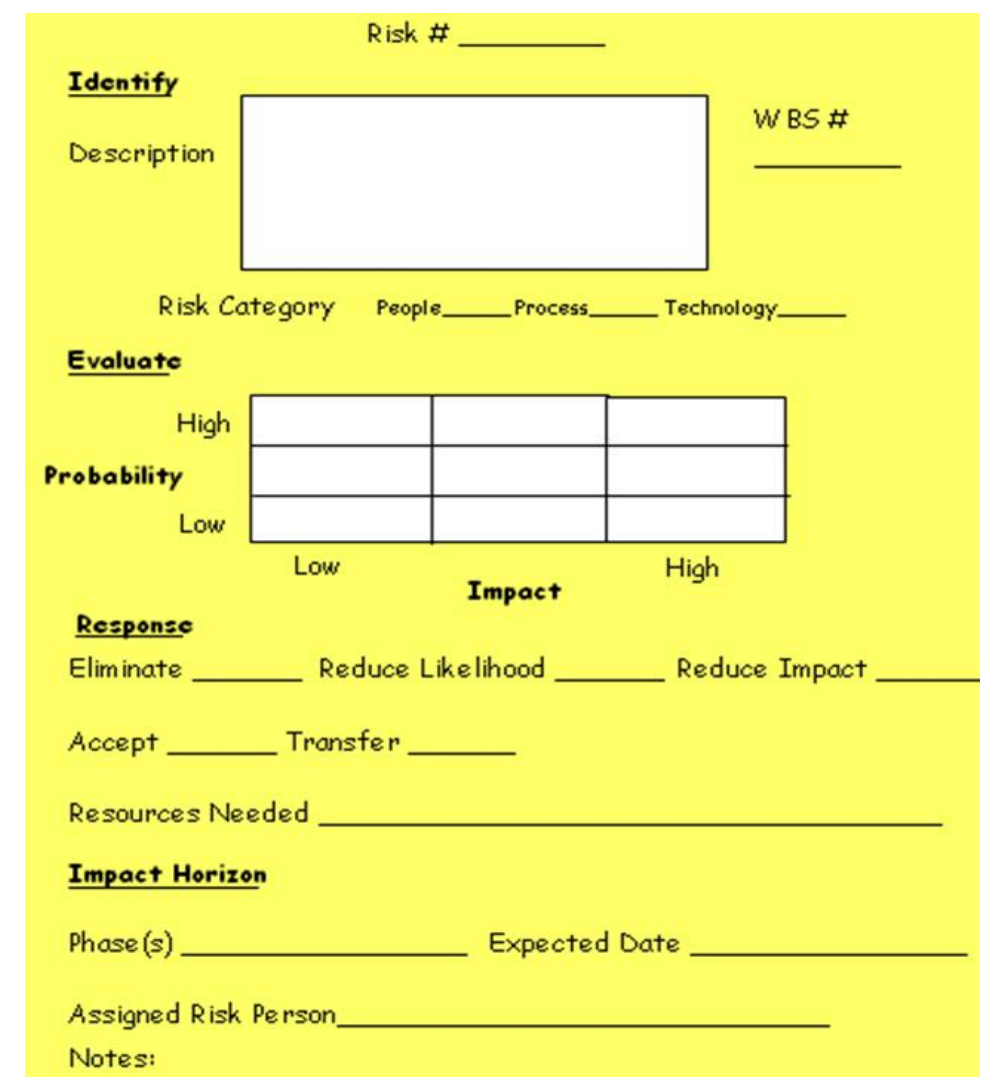

Figure 4: USAA Risk Management Card

\section{Lesson 7: Costing}

Direct cost such as labor, other direct cost (ODC), total direct cost (TDC) and indirect costs such as overhead, G\&A, total direct and indirect (TDID) cost were introduced to the students. Profit, price, bill of materials (BOM), firm fixed price and cost-plus contract types were discussed. Due to the nature of the HUNCH projects, these concepts were not discussed or used in previous years' projects. However, these concepts are critical for the business world and the students should be exposed to them. The high school teams were impressed with what value they were providing to NASA through this STEM experiential learning opportunity.

\section{Lesson 8: Planning Wrap Up}

This lesson served as a wrap up for the project planning. All the concepts from previous lessons were reviewed. A Gantt Chart was used to capture the project calendar information with key events depicted. Relationships among various tools such as WBS, RAM, NLD, and Gantt Chart were discussed.

\section{Lesson 9: Earned Value}

This lesson covered the project control and reporting. Students were tasked to use budgeted time and cost to get a big picture view for managing and reporting the health of the overall project. Budget Cost of Work 
Performed (BCWP) or Earned Value, Budget Cost of Work Scheduled (BCWS) or Planned Value, and Actual Cost of Work Performed (ACWP) or Actual Value were used to calculate the Schedule Performance Index (SPI) and Cost Performance Index (CPI) to measure the status and trend of the project:

$\mathrm{SPI}=\mathrm{BCWP} / \mathrm{BCWS} \quad($ Earned/Planned $)$

$\mathrm{CPI}=\mathrm{BCWP} / \mathrm{ACWP} \quad($ Earned/Actual $)$

A plot of SPI vs CPI, as illustrated in Figure 5 was used to determine whether the project was ahead/behind schedule and over/under budget (Terkelsen, 2008; Zhan \& Morgan, 2011). The x in Fig. 5 indicates that the project is behind schedule and over budget.

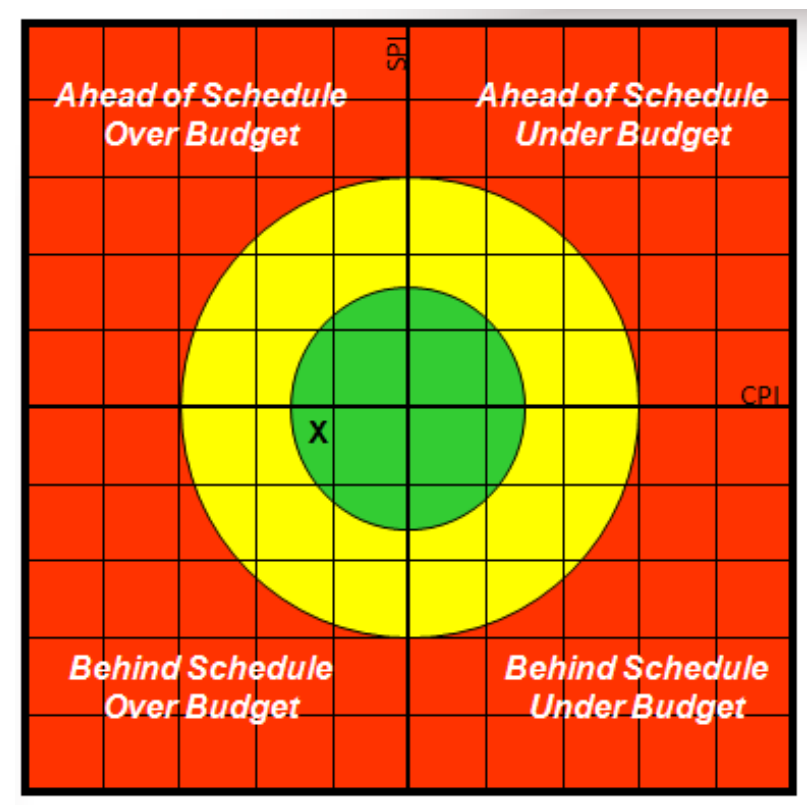

Figure 5: SPI vs. CPI

\section{Lesson 10: Project Management Career Discussion by a Practitioner}

PMI-CLG called on volunteers from its Project Management Professionals (PMP) membership to deliver this lesson. The PMI member shared his experience over the years in managing various projects. This provided a connection between the first nine lessons learned and the real-world experience of an actual project manager.

During the ten weeks of workshop, the high school students gained exposure to project management tenets, contacts in various industries and mentors for their project management careers.

High school students are minors, and there are strict regulations on how faculty members and undergraduate students can communicate with them. This unique challenge required some creative approach, as indicated by other educators (Byrne et al., 2008). A wiki communication protocol was used to meet the requirement. The home page of the website is illustrated in Fig. 6. 


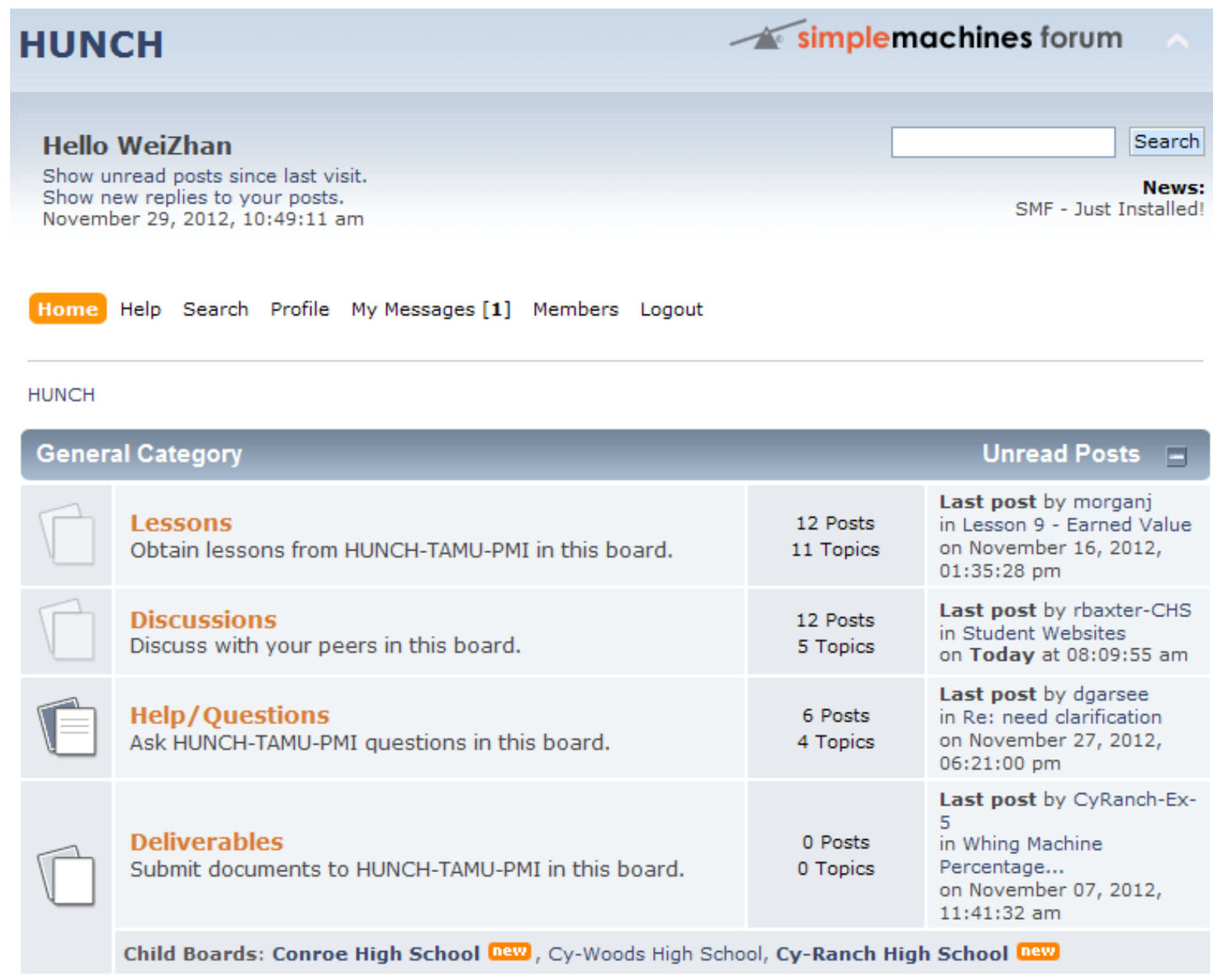

Figure 6: Website for HUNCH Projects

Under the direction of the Co-PIs, EET undergraduate students established and maintained this resource. High school students were asked to register with user names without using their real names. Only the website manager, one of the faculty members, knows the identities of the student users. The high school teachers, the undergraduate mentors, and the faculty members all used real names. The wiki site allowed students to log in and use and contribute to the learning community for these projects. Students could download course materials such as power point presentations, Excel files, and other graphical tools. Students could post questions and start a discussion thread. They could also submit assignments for the faculty members to grade. To promote interaction among the three high schools, individual subdirectories for each high school were created. These subdirectories were made viewable by everyone, but each school could only edit their own subdirectory.

\section{EVALUATION OF STUDENTS' LEARNING}

A combination of classroom lecturing and project-based learning was used. After each lecture, students were tasked to use what they learned in their $\mathrm{HUNCH}$ project. The project-based learning re-enforced the knowledge acquired during the lectures. This method seemed to work well with the high school students. To evaluate the effectiveness of the students' learning of the project management materials, pre- and post- tests were designed and conducted in each high school. The pre-test was designed by faculty members at Texas A\&M University and conducted by the high school teachers prior to the commencement of the lectures. After all the lectures were delivered, a post-test was conducted by the high school teachers. The pre- and post-tests were exactly the same. Neither the students nor the high school teachers knew that the two tests were the same. The pre-test 
results were graded by Texas A\&M faculty members and the grades were returned to the high school teachers and the students. Solutions were not provided to the students or high school teachers.

There were twenty-six students participating in the pre-test and twenty-eight students participating in the post-test, with 2 students added to the class after the pre-test. The tests consist of 25 multiple choice problems. Each problem had five choices, one of which is "I don't know". There was no penalty for selecting a wrong answer. If a student randomly selected answers, his/her score would be around 20\%. The raw data are displayed in Table 1 . The statistics of the two test results are summarized in Table 2.

Table 1: Pre- and Post-Test Results

\begin{tabular}{|l|r|r|r|r|r|r|r|r|r|r|r|r|r|r|r|r|r|r|r|r|r|r|r|r|r|r|r|r|}
\hline pre & 28 & 36 & 20 & 12 & 36 & 44 & 40 & 24 & 44 & 32 & 40 & 28 & 0 & & & 20 & 16 & 28 & 12 & 16 & 16 & 40 & 8 & 8 & 44 & 27 & 32 & 28 \\
\hline post & 56 & 60 & 44 & 28 & 60 & 60 & 24 & 52 & 60 & 44 & 44 & 40 & 56 & 48 & 48 & 36 & 36 & 80 & 52 & 64 & 24 & 56 & 72 & 52 & 56 & 52 & 60 & 60 \\
\hline
\end{tabular}

Table 2: Test Statistics

\begin{tabular}{|c|c|c|c|c|c|}
\hline & mean & std & min & $\max$ & range \\
\hline Pre-test & 26.1 & 12.8 & 0 & 44 & 44 \\
\hline Post-test & 50.9 & 13.4 & 24 & 80 & 56 \\
\hline
\end{tabular}

The averages for the pre- and post-test are $26.1 \%$ and 50.9\% respectively. Using Minitab software, one can easily calculate the $95 \%$ confidence level for the means of the pre- and post-tests to be $(21.0,31.2)$ and $(45.5,56.6)$. The pre-test average is very close to the $20 \%$ score if the answers were selected randomly. The post-test average is significantly higher than that of the pre-test scores and the $20 \%$ random selection score.

Because the goal is to discover whether the mean for the post- test scores is significantly better than that of the pre- test scores, the most appropriate analysis tool is the paired t-test with the following hypotheses:

$\mathbf{H}_{0}: \quad \mu_{1}=\mu_{2}$ (The pre- and post-test had the same mean.)

$\mathbf{H}_{1}$ : $\quad \mu_{1}>\mu_{2}$ (The post-test scores had a greater mean than that of the pre-test scores.)

Since the sample size of 26 was sufficiently large, according to the Central Limit Theorem, the average can be approximated by a Normal distribution. Therefore, there is no need to check for normality for the raw data in order to use the paired t-test. The mean and standard deviation for the difference between the post- and pre- tests (pre- subtracted from post-) are calculated as 24.96 and 17.61, respectively. It is worth mentioning that one student had lower post scores than the pre score, which is not reasonable. This data point is not deleted or manipulated (for example, making the difference equal to 0 ).

The paired t-test is to compare the following quantity to $t_{0.05,25}=1.708$.

$t=\frac{\bar{d}}{s_{d} / \sqrt{n}}$

where $n$ is the sample size and equal to 26 in this analysis, $\overline{\boldsymbol{d}}$ is the difference between the means of the post- and pre- test scores, $s_{d}$ is the standard deviation of the difference, $t_{0.05,25}$ is the value in the t-distribution table. A $95 \%$ confidence level is used. The $t$ value in equation (3) can be easily calculated as 7.23, which is much greater than $t_{0.05}$, ${ }_{25}(=1.708)$. Therefore, with a confidence level of $95 \%$, the null hypothesis $H_{0}$ is rejected and the alternative hypothesis $H_{l}$ is accepted. In other words, one can conclude with $95 \%$ confidence level that the students' knowledge levels in project management have significantly improved during the ten weeks' time.

One goal that the Texas A\&M / PMI-CLG team had was to provide a level of education and project management experience for high school students necessary to sit for the Certified Associate Project Management $\left(\mathrm{CAPM}^{\circledR}\right)$ examination. PMI states that the CAPM ${ }^{\circledR}$ is designed for those with little or no project experience and demonstrates an understanding of the fundamental knowledge, terminology and processes of effective project management. The top performers in the post-test will be sponsored to take the CAPM ${ }^{\circledR}$ exam. 
Although the pre- and post- tests showed significant improvement in students' knowledge in project management, the average score is not as high as one might have expected. This may have been caused by a NASA employee supporting the technical development of the $\mathrm{HUNCH}$ projects unexpectedly leaving for other opportunities. Students were delayed in their projects and could not take full advantage of "learning by using". This problem will be addressed and it is expected that students will gain more knowledge while using the project management tools to manage their projects during the execution phase. Students will be given a survey at the end of their projects to gather more information about the design and implementation of the educational modules, the strengths versus areas for improvement, and the impact on the students' interests in STEM. Since the project duration is one year, the evaluation options are limited. If NASA continues to sponsor the project next year, more effort will be focused on evaluation of the effectiveness of the teaching method and impact on students. Project management, as other 21st Century skills required by industry (Trilling \& Fadel, 2009), is harder to evaluate in classroom compared to other academic skills. The real benefit will be seen after the students join the workforce as engineers. With the knowledge of project management, they will be able to manage their project more efficiently.

\section{CONCLUSIONS AND DISCUSSION}

Texas A\&M University and PMI-CLG deployed an innovative approach to teach project management to high school students. This approach combines the educational expertise and real-world experience of practitioners in the field. Various teaching methods were used, including in-person lecturing, WebEx, videotaping, and wiki website communication. College seniors mentored the high school students and teachers in applying the project management tools and practices to their specific projects. By participating at this level, the college students were fully aware of the status of the projects and provided continuity and reinforcement of the lessons through the position of mentor and advisor to the team. In addition to establishing a close working relationship with the high school students working on the NASA HUNCH projects, the EET students reinforced their own learning of project management principles by teaching them to others.

Texas A\&M University and PMI-CLG provided the participants of the HUNCH projects a valuable understanding of how project management skills can be applied in a variety of STEM-related industries and applications. This exposure to real-life application of curriculum will help motivate the participants to pursue the credentials that these organizations value.

Statistical analysis of the test scores show that the students gained a significant amount of knowledge in project management. Additional learning will happen as the students apply project management tools and concepts to their projects. More evaluation will be conducted for further analysis.

The established model can be readily transferred to other regions through partnerships which are established by other PMI groups and educational institutions.

\section{ACKNOWLEDGEMENT}

The Authors would like thank NASA and the HUNCH program for supporting this effort for STEM education and outreach activity.

\section{AUTHOR INFORMATION}

Joseph A. Morgan has over 20 years of military and industry experience in electronics and telecommunications systems engineering. He joined the Engineering Technology and Industrial Distribution Department in 1989 and has served as the Program Director of the Electronics and Telecommunications Programs and as the Associate Department Head for Operations. He received his BS degree in electrical engineering (1975) from California State University, Sacramento, and his MS (1980) and DE (1983) degrees in industrial engineering from Texas A\&M

University. His education and research interests include project management, innovation and entrepreneurship, and embedded product/system development. E-mail: morgan@entc.tamu.edu 
Dr. Wei Zhan is an Associate Professor of Electronic Systems Engineering Technology at Texas A\&M University. Dr. Zhan earned his D.Sc. in Systems Science from Washington University in St. Louis in 1991. From 1995 to 2006, he worked in the automotive industry as a system engineer. In 2006, he joined the Engineering Technology and Industrial Distribution Department at Texas A\&M University. His research activities include control system theory and applications to industry, system engineering, robust design, modeling, simulation, optimization, quality control, project management, and STEM education. E-mail: zhan@entc.tamu.edu (Corresponding author)

Matthew Leonard is a lecturer in the Electronic Systems and Engineering Technology Program at Texas A\&M. Mr Leonard has more than 25 years of experience in the aerospace industry, primarily with the National Aeronautics and Space Agency in increasingly more complex project management positions, including most recently being the Deputy Project Manager for NASA's Lunar Surface Systems project. Mr. Leonard is the ESET programs technical expert on Product Development and Systems Engineering. Mr. Leonard recently established a startup company in the Bryan College Station Texas area, Texas Space Technology Applications and Research (T STAR) Inc.

\section{REFERENCES}

1. Alliance for Excellent Education. (2008). How Does the United States Stack Up? Retrieved from http://www.all4ed.org/files/IntlComp_FactSheet.pdf

2. Byrne, J. J., Snyder, J., \& Seward, D. (2008). Project Management's Future: Teaching Project Management to High School Students Using Project Learning. PMI Global Congress Proceedings, Denver, Colorado, 2008.

3. Carlson, L. E., \& Sullivan, J. F. (1999). Hands-on engineering: Learning by doing in the integrated teaching and learning program. International Journal of Engineering Education 15(1): 20-31.

4. Cejka, E., Rogers, C., \& Portsmore, M. (2006). Kindergarten robotics: Using robotics to motivate math, science, and engineering literacy in elementary school," International Journal of Engineering Education 22(4), pp. 711-722.

5. Center for Science, Mathematics, and Engineering Education, Committee on Undergraduate Science Education. (1999). Transforming undergraduate education in science, mathematics, engineering, and technology. Washington, D.C.: National Academy Press.

6. Cunningham, C. M., \& Hester, K. (2007). Engineering is elementary: An engineering and technology curriculum for children," Proceedings of the American Society for Engineering Education Annual Conference. Honolulu, HI.

7. Cunningham, C. M., Lachapelle, C., \& Lindgren-Streicher, A. (2005). Assessing elementary school students' conceptions of engineering and technology. Proceedings of the Annual conference of the American Society of Engineering Education. Portland, OR.

8. DeHaan, R. L., \& Schuck, J. A. (2003). Improving undergraduate instruction in science, technology, engineering, and mathematics: Report of a workshop. National Academy Press.

9. Douglas, J., Iversen, E., \& Kalyandurg, C. (2004). Engineering in the k-12 classroom: An analysis of current practices and guidelines for the future. Washington, DC: American Society for Engineering Education. http://www.engineeringk12.org/Engineering in the K-12 Classroom.pdf

10. Douglas, S. (2006). The infinity project: On the design and implementation of a high school engineering curriculum. Proceedings of the American Society for Engineering Education Annual Conference. Chicago, IL, 2006.

11. Erwin, B., M. C., \& Rogers, C. (2000). LEGO engineer and ROBOLAB: Teaching engineering with LabVIEW from kindergarten to graduate school. International Journal of Engineering Education. 16(3): $181-92$.

12. Fairweather, J. (2010). Linking Evidence and Promising Practices in Science, Technology, Engineering, and Mathematics (STEM) Undergraduate Education, A Status Report for The National Academies National Research Council Board of Science Education. Washington D.C.

13. Fisher, D., Schluter, L., \& Toleti, P. (2005). Project Management Education and Training Process for Career Development. Journal of Construction Engineering and Management, Vol. 131, No. 8, pp. 903-910.

14. Gelano, L. J., Bruning, M., \& Adams, B. (2000). Creating a K-12 engineering educational outreach center. Proceeding in 2000 ASEE Annual Conference. American Society for Engineering Education, Washington, D.C. 
15. Heerkens, G. (2001). Project Management (The Briefcase Book Series), McGraw-Hill.

16. Hirsch, L. S., Gibbons, S. J., Kimmel, H., Rockland, R., \& Bloom, J. (2003). High school students' attitudes to and knowledge about engineering. Proceedings of the 33rd Annual Conference for Frontiers in Education, ed. S. J. Gibbons. Boulder, CO.

17. Hirsch, L. S., Kimmel, H., Rockland, R., \& Bloom, J. A. (2005). Implementing pre-engineering curricula in high school science and mathematics. Proceedings of the 35th Annual Conference Frontiers in Education, ed. H. Kimmel. Indianapolis, IN.

18. Hriso, P., \& Clark, W. A. (2007). Project management through experiential learning. Proceedings of the Annual Conference of American Society for Engineering Education.

19. Hummel, R., Cheetham,P., \& Rossi, J., (2012). "US Science and Technology Leadership, and Technology Grand Challenges," Synesis: A Journal of Science, Technology, Ethics, and Policy, pp. 14-39.

20. Hunter, M. A. (2006). Opportunities for environmental science and engineering outreach through k-12 mathematics programs. Environmental Engineering Science. 23(3): 461-71.

21. Jack H., \& Pung, C. (2009). A web-based approach to senior undergraduate project management," Proceedings of the Annual Conference of American Society for Engineering Education.

22. Jeffers, A. T., Safferman, A. G., \& Safferman, S. I. (2004). Understanding k-12 engineering outreach programs. Journal of Professional Issues in Engineering Education and Practice. 130(2): 95-108.

23. Katehi, L., Pearson, G., \& Feder, M. (Eds.). (2009). Engineering in K-12 education: Understanding the status and improving the prospects. Washington, D.C: The National Academies Press.

24. Kerzner, H. (2005). Project Management: A Systems Approach to Planning, Scheduling, and Controlling (9th ed.).

25. Kimmel, H., Carpinelli, J., Alexander, L. B., \& Rockland. R. (2006). Bringing engineering into k-12 schools: A problem looking for solutions? Proceedings of the American Society for Engineering Education Annual Conference and Exposition. Chicago, IL.

26. Knezek, G., Christensen, R., \& Tyler-Wood, T. (2011). Contrasting perceptions of STEM content and careers. Contemporary Issues in Technology and Teacher Education, 11(1), pp. 92-117.

27. Koonce, D. A., Zhou, J., Anderson, C. D., Hening, D. A., \& Conley, V. M. (2011). What is STEM? ASEE Annual Conference Proceedings.

28. Kuprenas, J. \& Nasr, E. (2006). Project management training and certification for a public sector engineering organization. Proceedings of the Annual Conference of American Society for Engineering Education.

29. Kuprenas, J. A., Madjidi, F., \& Alexander, A. S. (1999). A Project Management Training Program. Journal of Management in Engineering, Vol. 15, No. 6, pp. 47-55.

30. Lacey, T. A., \& Wright, B. (2009). Occupational employment projections to 2018. Monthly Labor Review, pp. 82-123.

31. Lachapelle, C. P., \& Cunningham, C. (2007). Engineering is elementary: children's changing understandings of science and engineering. Proceedings of the American Society for Engineering Education Annual Conference \& Exposition. Honolulu, HI.

32. Library of Congress. (2008). CRS report for Congress: Science, technology, engineering, and mathematics (STEM) education: Background, federal policy, and legislative action (Updated March, 2008). Washington, DC: Congressional Research Service.

33. Milosevic, D. Z. (2003). Project Management ToolBox: Tools and Techniques for the Practicing Project Manager. Wiley.

34. Moore, K., Fairweather, J., Amey, M., Ortiz, A., Mabokela, R., \& Ruterbusch, M. (2000). Best practices for reform in undergraduate education in science, math, engineering, \& technology: A knowledge framework. East Lansing, MI: Center for the Study of Advanced Learning Systems, Michigan State University.

35. Morgan, J. A., Wright, G., \& Porter, J. R. (2005). Managing Senior Design Projects to Maximize Success: The TAT Team," American Society of Engineering Education Annual Conference, Portland, Oregon.

36. National Science Board. (2004). Science and Engineering Indicators. Volume 2.

37. National Science Board. (2007). Moving toward to improve engineering education. Arlington, VA: NSF Publications.

38. National Science Foundation. (1996). Shaping the future: New expectations for undergraduate education in science, mathematics, engineering, and technology. Washington, D.C.: National Science Foundation. 
39. National Science Foundation. (2012). Science, Technology, Engineering, and Mathematics Talent Expansion Program (STEP), 2012. http://www.nsf.gov/pubs/2011/nsf11550/nsf11550.pdf

40. Ncube, L. (2006). Preparing tomorrow's engineers and engineering technologists: An evaluation of the Project Lead The Way outreach program for middle and high school students in Indiana. Proceedings of the Annual Conference of American Society for Engineering Education. Chicago, IL.

41. Newell, M., \& Grashina, M. (2003). The Project Management Question and Answer Book, American Management Association.

42. Olds, B. M., Pavelich, M. J., \& Yeatts, F. R., (1990). Teaching the Design Process to Freshmen and Sophomores," Journal of Engineering Education, July/August, pp. 554-559.

43. Porter, J. R., Zoghi, B., \& Morgan, J. A. (2002). Integrating Project Management into the Capstone Senior Design Course. American Society of Engineering Education Annual Conference, Montreal, Canada, June 16-19.

44. Project Management Institute. (2009). A guide to the project management body of knowledge (PMBOK $®$ Guide) 4th ed., Newtown Square, PA: Project Management Institute.

45. Raymond, T., (2007). Non-Traditional Courses for Applying Stem Knowledge. Proceedings of ASEE Annual Conference.

46. Scott, C. (2012). An Investigation of Science, Technology, Engineering and Mathematics (STEM) Focused High Schools in the U.S.," Journal of STEM Education, Vol. 13, No. 5, pp. 30-39.

47. Smit, I. (1998). Teaching project management skills using project management - a true hands-on experience. Proceedings of the Annual Conference of American Society for Engineering Education.

48. Subotnik, R.F., Tai, R.H., Rickoff, R., \& Almarode, J. (2010). Specialized Public High Schools of Science, Mathematics, and Technology and the STEM Pipeline: What Do We Know Now and What Will We Know in 5 Years? Roeper Review, 32, 7-16.

49. Sundaram, R., \& Zheng, Q. (2010). STEM-based Projects to Integrate the Undergraduate ECE Program with the K-12 STEM Curriculum. Proceedings of ASEE Annual Conference.

50. Terkelsen, J. (2008). Earned value user's guide. Capstone design project report, Department of Engineering Technology \& Industrial Distribution, Texas A\&M University.

51. Trilling, B. \& Fadel, C. (2009). 21 st century skills: learning for life in our times. San Francisco, CA: Jossey-Bass. http://www.21stcenturyskillsbook.com/index.php

52. Zhan, W., \& Morgan, J. A. (2011).Visual project management tools and their application. Journal of Management and Engineering Integration, Vol. 4, No. 1, pp. 137-144.

53. Zhan, W., Zoghi, B., \& Fink, R. (2009). The Benefit of Early and Frequent Exposure to Product Design Process", Journal of Engineering Technology, Spring, pp. 34-43.

54. Zhan, W., Crenshaw, J., Hurst, T., \& Schulz, J. (2008). Addressing the Engineering Needs of the Nuclear Power Industry”, Proceedings of The 13th Annual International Conference on Industry, Engineering, and Management Systems, pp. 75-79. 


\section{NOTES}

